JAMALI - Jurnal Abdimas Madani dan Lestari

Vol. 01, Issue. 01, Maret 2019, Hal 24-33

(e-ISSN: - ; p-ISSN: - )

https://journal.uii.ac.id/JAMALI

\title{
Pengenalan Hak-Hak Konstitusional Warga Negara di Sekolah ${ }^{1}$
}

\author{
Dian Kus Pratiwi, ${ }^{2}$ Dessy Ariani, ${ }^{3}$ Despan Heryansyah \\ Fakultas Hukum Universitas Islam Indonesia \\ Email: diankus.pratiwi@uii.ac.id
}

\begin{abstract}
Abstrak
Sebagai negara yang berdasarkan hukum, maka salah satu yang menjadi indikatornya adalah adanya jaminan hak asasi manusia dan hak warga negara. dalam konteks negara yang berkedaulatan rakyat maka perlu sebuah pemahaman yang baik terkait hak-hak Konstitutional yang dimiliki oleh warga negara. rendahnya minat warga negara menggunakan hak pilihnya dalam proses demokrasi menjadi salah satu indikator kurangnya pengenalan hak-hak warga negara. salah satu peran sekolah adalah seain sebagai tempat menjadi ilmu namun juga sebagai tempat edukasi. Maka dalam kegiatan pengabdian ini dilakukan pengenalan hak-hak constitutional warga negara di sekolah. Metode kegiatan yang dilakukan dengan cara sosialisasi dan Tanya jawab secara langsung dengan peserta didik. Hasil pengabdian menunjukan bahwa, tingginya keingintahuan peserta didik terkait dengan apa itu hak constitutional warga negara, apa macam-macamnya, dan bagaimana proses pelaksanaan hak konstititutional warga negara tersebut. Perlu untuk melanjutkan sosialisasi yang serupa pada tahuntahun berikutnya. Agar siswa-siswi lain juga memahami dan mengetahui hak konstitusionalnya sebagai warga negara. Hal ini penting dilakukan mengingat jumlah peserta dalam kegiatan sosialisasi ini sangat terbatas sehingga tidak semua siswa dapat ikut serta.
\end{abstract}

\section{Latar Belakang Masalah}

Negara Indonesia adalah Negara hukum. Dalam sebuah Negara hukum maka tonggak pemerintahan Negara dipimpin oleh hukum. Beberapa ciri-ciri Negara hukum diantaranya adalah, adanya jaminan terhadap hak waga negara yang diatur di dalam hukum dasar sebuah Negara.

Indonesia sebagai Negara hukum, berpegang teguh pada hukum dasar kita yakni UUD Negara Reublik Indonesia tahun 1945 dan phylosophie grondslag bangsa Indonesia yakni Pancasila. Baik dalam dasar filosofi bangsa Indonesia maupun hukum dasar Negara Indonesia diatur secara tegas hakhak konstitusional warga Negara Indonesia. Bahkan hak-hak konstusional warga Negara diwujudkan untuk mencapai tujuan keadilan social bagi seluruh Indonesia.

UUD Negara Republik Indonesia mengatur secara eksplisit maupun implisit hak warga Negara, diantaranya adalah hak untuk mengeluarkan pendapat secara lisan maupun tulisan. Hak demokrasi yang kemudian ita kenal ini juga diatur secara tegas dalam Pancasila sila ke 4.

Indonesia sebagai negara yang demokratis, di dalamnya rakyat secara aktif berperan langsung dalam menentukan pemimpinnya. Demokrasi secara langsung telah dimulai sejak Indonesia mengadakan Pemilihan Umum pertama kali pada tahun 1955. Dalam perjalanan ketatanegaraannya,

\footnotetext{
${ }^{1}$ Hasil Hibah Pengabdian dari Direktorat Penelitian dan Pengabidian Masyarakat Universitas Islam Indonesia

${ }^{2}$ Dosen Fakultas Hukum Universitas Islam Indonesia, Jl. Tamansiswa No. 158 Yogyakarta, email: dian.pratiwi.sh@gmail.com dan Peneliti di Pusat Study Hukum Dan Konstitusi (PSHK) FH UII Yogyakarta Jl. Lawu No. 1 Kotabaru Yogyakarta

${ }^{3}$ Peneliti di Pusat Study Hukum Dan Konstitusi (PSHK) FH UII Yogyakarta Jl. Lawu No. 1 Kotabaru Yogyakarta
} 
pasca reformasi 1998, gelombang tuntutan demokrasi semakin besar di Indonesia. Pasca jatuhnya rezim Orde Baru dan dilakukannya amandemen UUD 1945, mengembalikan nafas negara Indonesia ke dalam demokrasi secara langsung. Hal ini ditandai dengan perubahan Pasal 1 ayat 2 UUD 1945 menjadi "Kedaulatan di tangan ranyat dan di laksanakan menurut Undang-Undang". Sebagai konsekuensi dari pasal inilah rakyat mendapat untuk menentukan pilihan politiknya secara langsung baik untuk pemimpin tingkat nasional maupun tingkat daerah. Di tingkat nasional rakyat Indonesia berperan aktif dalam pemilihan Presiden dan Wakil Presiden Republik Indonesia dan juga Pemilihan Legislatif yakni DPR dan DPD.

Implementasi dari hak-hak konstitusional warga Negara ini adalah pemerintahan Negara Indonesia harus berdasarkan atas kehendak rakyat. Rakyat mempunyai andil dalam setiap pengambilan kebijakan Negara. Hal ini dikarenakan pemilik kedaulatan sesungguhnya adalah rakyat.

Minimnya kesadaran berkonstitusi di Indonesia, ditengarai karena kurangnya pengetahuan maupun kesadaran hak konstitusional warga Negara. Kesadaran kan hak-hak konstitusional menjadi poin yang penting dalam membangun bangsa Indonesia kearah yang lebih baik.

Kesadaran berkonstItusi tidak hanya di mulai dari usia dewasa, pada saat mengunakan hak pilihnya, namun juga harus dimulai pada usia dini anak-anak bangsa Indonesia. Keluarga, masyarakat maupun sekolah menjadi sarana penanam hak-hak konstitusional ini.

Pengenalan hak-hak konstitusional di sekolah, dirasa efektif khususnya bagi para siswa didik. Hak ini dikarenakan anak setiap hari berinteraksi dan mendapat ilmu pengetahuan di sekolah. Pengenalan hak-hak konstitusional warga Negara di sekolah dapat melalui media pembelajaran secara langsung. Sehingga harapannya si anak dapat empraktekan dalam kehidupan sehari-hari.

Adapun permasalahan yang ditemui siswa-siswi diantaranya adalah sebagai berikut:

1. Kurangnya kesadaran berkonstitusi warga negara, sehingga minimnya pengetahuan tentang hak-hak konstitusional warga negara. Sehingga mengaburkan kesadaran berbangsa dan bernegara di masyarakat.

2. Sikap apatisme waga negara terhadap partisipasi dalam kehidupan berbangsa dan bernegara yang kemudian di implementasikan dengan sikap apatis dalam proses berdemokrasi baik pusat maupun daerah melalui pemilihan umum.

3. Degrasai terhadap nasionailisme dan patriotisme sehingga mudah untuk dipecah belah dengan isu-isu sensitif seperti SARA yang dapat ditakutkan mengancam keutuhan Negara Kesatuan Republik Indonesia.

Pengenalan hak-hak konstitusional sejak dini, akan memberikan mafaat di masa yang akan datang salah satunya yaitu timbulnya jiwa nasionalisme dan patriotisme dalam diri masing-masing warga Negara. Hal ini mejadi penting karena dewasa ini semangat nasionalisme maupun patriotisme yang ada di Indonesia menurun. Terbukti dengan banyaknya kerusuhan yang di picu oleh SARA, mapun apatisnya warga Negara dalam proses demokrasi. Hal ini dikarenakan pengenalan hak-hak konstitusional warga Negara tidak berhasil dimasyarakat kita. Dengan kesadaran hak-hak konstitusional warga negara, maka diharapkan setiap warga negara merasa memiliki Indonesia sebagai sebuah kesatuan yang utuh. Untuk itu dirasa perlu melakukan sebuah kegiatan tentang pengenalan hakhak konstitusional warga negara di sekolah.

\section{Rumusan Masalah}

1. Bagaimana Hak Konstitusional warga negara dalam kehidupan bermasyarakat?

2. Bagaimana Hak Konstitusional waga negara dalam kehidupan berdemokrasi?

\section{Metode Pengabdian}

\section{Metode Pengabidan}

Adapun metode kegiatan Pengabdian ini adalah : 
a. Sosialisasi Hak Konstitusional Warga Negara

Kegiatan ini dalam rangka memberikan pendidikan kesadaran berkonstitusi. Kegaian ini dimaksudkan untuk memberikan pengetahuan dan pemahaman terkait hak konstitusional warga negara. Format kegiatan adalah penyampaian materi dengan narasumber Dessy Ariani, SH., MH. dan Dian Kus Pratiwi, SH., MH. serta Despan Heryansyah, SH., MH. sebagai moderator.

\section{b. Tanya Jawab Hak Konstitusional Warga Negara}

Bentuk kegiatan ini adalah tanya jawab lansung antara peserta dan pembicara. Kegiatan ini akan dipandu oleh dua peneliti dari Pusat Studi Hukum Konstitusi FH UII. Kegiatan ini akan mengeksplor lebih jauh pemahaman warga negara (siswa SMA) terkait hak konstitusional warga negara. Dalam sesi tanya jawab ini, peserta akan diberikan kesempatan untuk mengemukakan pendapat serta pandangannya terkait persoalan hak konstitusional warga negara.

\section{Narasumber dan Materi}

\begin{tabular}{|l|l|l|}
\hline No. & \multicolumn{1}{|c|}{ Narasumber } & \multicolumn{1}{|c|}{ Materi } \\
\hline 1. & $\begin{array}{l}\text { Dessy Ariani, SH, MH. (Peneliti PSHK } \\
\text { FH UII) }\end{array}$ & $\begin{array}{l}\text { Hak Konstitusional warga negara } \\
\text { dalam kehidupan bermasyarakat }\end{array}$ \\
\hline 2 & $\begin{array}{l}\text { Dian Kus Pratiwi, SH.,MH. (Dosen FH } \\
\text { UII) }\end{array}$ & $\begin{array}{l}\text { Hak Konstitusional waga negara dalam } \\
\text { kehidupan berdemokrasi }\end{array}$ \\
\hline
\end{tabular}

\section{Tempat dan Waktu Pelaksanaan}

Kegiatan ini direncanakan akan dilaksanakan pada:

Hari dan Tanggal : Rabu, 25 Januari 2017

Tempat Pelaksanaan : SMA N 1 BANTUL

Waktu :08.30-12.00WIB

\section{Peserta Kegiatan}

a. Latar Belakang Peserta

Peserta adalah siswa didik di SMA N 1 Bantul yang terdiri dari siswa kelas 3. Selain itu juga mengundang Bapak Ibu guru pengampu mata pelajaran Pendidikan Kewarganegaraan.

b. Jumlah Peserta

Adapun Jumlah Peserta dalam Sosialisasi ini adalah 100 orang.

\section{Pembahasan}

SMA N 1 Bantul merupakan salah satu SMA terbaik di Kabupaten Bantul, juga dapat dikatakan sebagai SMA terbaik di Jogjakarta. Oleh karena itu, SMA ini dapat dijadikan sebagai tolak ukur sumber daya manusia siswa/siswi SMA di Kabupaten Bantul secara keseluruhan. Dengan fasilitas serta dewan guru yang cukup memadai (karena mayoritas berpendidikan S2) maka tingkat pengetahuan peserta didik sejatinya sudah lebih baik.

Sebagai mana telah penulis paparkan dalam BAB I terdahulu bahwa kondisi pemahaman apalagi kesadaran warga negara khususnya anak-anak SMA terhadap hak konstitusional warga negara sangat rendah ternyata sesuai dengan realitas di lapangan. Hal ini kami simpulkan setelah melakukan diskusi terhadap siswa-siswi SMA N 1 Bantul. Secara umum memang mereka mengetahui bahwa bangsa Indonesia memiliki konstitusi yaitu UUD Negara Republik Indonesia Tahun 1945. Bahkan sebagian dari mereka memahi sejarah terbentuknya UUD, sejak masih dibahas dalam sidang BPUPKI. 
Namun demikian, pada saat ditanya tentang apa saja yang terkandung di dalam konstitusi, tidak satupun peserta yang berhasil menjawab dengan benar. Ini artinya, peserta juga tidak memahami bahwa di dalam UUD 1945 itu terdapat hak-hak dasar warga negara atau yang dikenal dengan istilah hak konstitusional. Padahal ini menyangkut hak setiap warga negara yang dibawa sejak lahir dan wajib di jamin oleh negara. Maksudnya negara wajib memenuhi, melindungi, dan mempertahankan hak konstitusional warga negara.

Kegiatan ini diawali dengan pemaparan singkat oleh moderator sebagai pembuka diskusi, kemudian dilanjutkan oleh Pemateri I yaitu Despan Heryansyah. Pemateri I menjelaskan tentang makna konstitusi bagi sebuah negara serta perannya dalam kehidupan berbangsa, bernegara, dan bermasyarakat. Pemateri juga memaparkan nilai-nilai yang terkandung di dalam Pancasila dan bagaimana Pancasila menjadi dasar bagi penyusunan Pasal-Pasal dalam UUD 1945.

Dilanjutkan dengan Pembicara II yang memaparkan mengenai sejarah terbentuknya konstitusi Indonesia, mulai dari pembahasan oleh Badan Penyelidik Usaha-usaha Persiapan Kemerdekaan Indonesia (BPUPKI), lalu disahkan pada tanggal 18 Agustus 1948, termasuk mengenai perubahan UUD 1945 dari tahun 1999-2002, hingga kandungak hak konstitusional warga negara yang terdapat dalam UUD. Pemateri membaginya menjadi 3 bagian untuk memudahkan peserta memahaminya, yaitu hak sipil, hak politik, dan hak ekonomi.

\section{Bagaimana Hak Konstitusional warga negara dalam kehidupan bermasyarakat?}

Perkembangan ketatanegaraan modern mengenal hak dasar yang dituangkan dalam konstitusi tersebut sebagai hak konstitusional. Menurut Prof. Jimly Asshiddiqie, Hak konstitusional merupakan hak-hak yang dijamin dalam dan oleh Undang-Undang Dasar (UUD) 1945. Penjaminan hak tersebut baik dinyatakan secara tegas maupun secara tersirat. Hak ini merupakan bentuk perlindungan hukum dari perbuatan yang dimungkinkan dilakukan oleh pemegang kekuasaan penyelenggara Negara dalam hubungan negara dan warga negara.

Hak konstitusional terkait pula akan pengakuan negara atas subjek dari hak konstitusional yakni warga negara. dalam hal warga negara, mereke ialah orang yang diakui secara hukum serta disahkan oleh undang-undang sebagai warga negara Indonesia. Oleh karena itu, ia mempunyai hak yang sama dalam hal apapun sebagai warga negara Indonesia.

Perlindungan dan penegakan hak-hak konstitusional merupakan kewajiban semua pihak, termasuk warga negara. Hak konstitusional tidak hanya mencakup mengenai hak, tetapi terkait pula mengenai kewajiban, yaitu kewajiban untuk saling menghormati dan menghargai hak konstitusional orang lain. Setiap hak konstitusional seseorang akan menimbulkan kewajiban dasar dan tanggung jawab untuk menghormati hak asasi orang lain secara timbal balik. Sehingga terdapat pembatasan dan larangan dalam pelaksanaan perlindungan hak asasi konstitusional Pembatasan yang ditetapkan melalui undang-undang dimaksudkan untuk menjamin pengakuan dan penghormatan atas hak dan kebebasan orang lain, dan untuk memenuhi tuntutan yang adil sesuai dengan pertimbangan moral, keamanan, ketertiban umum dan kepentingan bangsa.

Secara garis besar, konstitusi memuat tiga hal, yaitu pengakuan hak konstitusional, struktur ketatanegaraan yang mendasarkan dan pemisahan atau permbatasan kekuasaan. Konstitusi dapat di maknai sebaga hukum dasar yang menjadi sumber bagi peraturan lain yang berada di bawahnya, maka dapat disimpulkan bahwa keberadaan konstitusi adalah sebagai hukum tertinggi dalam suatu negara. Indonesia adalah negara yang menjunjung tinggi kedaulatan rakyat, yang berarti bahwa kekuasaan tertinggi berada di tangan rakyat, rakyat lah yang berkuasa dan rakyatlah sesungguhnya yang memiliki negara ini.

Oleh karena rakyatlah yang memiliki kedaulatan, maka segala aktifitas negara harus berdasarkan pada kepentingan rakyat dan persetujuan rakyat melalui para wakilnya di parlemen. Konstitusi bangsa 
Indonesia adalah UUD Negara Republik Indonesia Tahun 1945 atau dikenal dengan UUD 1945. UUD 1945 terdiri dari dua bagian, yaitu pembukaan dan Pasal-pasal. Pembukaan berisi cita negara yang kemudian dijabarkan dalam Pasal-pasal.

Di dalam Pembukaan terdapat lima dasar negara yang menjadi pedoman dalam kehidupan berbangsa, bernegara dan bermasyarakat. Kelima dasar negara ini tertuang dalam bentuk nilai, yang biasa kita sebut dengan istilah Pancasila. Sebagai sumber nilai, Pancasila membutuhkan penjabaran lebih lanjut agar dapat dipahami dengan konkret. Hal ini juga berkaitan dengan kedudukan Pancasila sebagai filsafat negara, yang bermakna seluruh aktifitas negara tidak dapat bertentangan dengan nilai2 Pancasila. Ada lima nilai yang terkandung di dalam Pancasila, yaitu:

1. Nilai Ketuhanan;

2. Nilai Kemanusiaan;

3. Nilai Persatuan

4. Nilai Kerakyatan, Hikmah, Bijaksana, Musyawarah; dan Perwakilan;

5. Nilai Keadilan.

Hak Konstitusional (constitutional rights) dapat diartikan sebagai hak asasi manusia yang telah tercantum dengan tegas dalam UUD Tahun 1945, sehingga juga telah resmi menjadi hak konstitusional setiap warga negara. Perbedaan antara hak konstitusional dengan hak legal, bahwa hak konstitusional adalah hak-hak yang dijamin di dalam dan oleh UUD Tahun 1945, sedangkan hak-hak hukum (legal right) timbul berdasarkan jaminan Undang-Undang dan Peraturan Perundang-undangan di bawahnya (subordinate legislations).

Sebagai pemegang kedaulatan tertinggi, warga negara memiliki hak-hak konstitusional yang dicantumkan dalam UUD 1945. Hak konstitusional berbeda hal nya dengan HAM yang sifatnya masih sangat universal. Hak-hak itu diantaranya dicantumkan dalam Pasal 27, 28, 29, 32 dan 34 yaitu:

1. Berhak atas bersamaan kedudukannya di dalam hukum dan pemerintahan dan wajib menjunjung hukum dan pemerintahan itu dengan tidak ada kecualinya;

2. Berhak atas pekerjaan dan penghidupan yang layak bagi kemanusiaan;

3. Setiap warga negara berhak dan wajib ikut serta dalam upaya pembelaan negara;

4. Hak atas Kemerdekaan berserikat dan berkumpul, mengeluarkan pikiran dengan lisan dan tulisan;

5. Setiap orang berhak untuk hidup serta mempertahankan hidup dan kehidupannya;

6. Setiap orang berhak membentuk keluarga dan melanjutkan keturunan melalui perkawinan yang sah;

7. Setiap anak berhak atas kelangsungan hidup, tumbuh, dan berkembang serta berhak atas perlindungan dari kekerasan dan diskriminasi;

8. Setiap orang berhak mengembangkan diri melalui pemenuhan kebutuhan dasarnya, berhak mendapat pendidikan dan memperoleh manfaat dari ilmu pengetahuan dan teknologi, seni dan budaya, demi meningkatkan kualitas hidupnya dan demi kesejahteraan umat manusia;

9. Setiap orang berhak untuk memajukan dirinya dalam memperjuangkan haknya secara kolektif untuk membangun masyarakat, bangsa dan negaranya;

10. Setiap orang berhak atas pengakuan, jaminan, perlindungan, dan kepastian hukum yang adil serta perlakuan yang sama di hadapan hukum;

11. Setiap orang berhak untuk bekerja serta mendapat imbalan dan perlakuan yang adil dan layak dalam hubungan kerja;

12. Setiap warga negara berhak memperoleh kesempatan yang sama dalam pemerintahan;

13. Setiap orang berhak atas status kewarganegaraan;

14. Setiap orang berhak memeluk agama dan beribadat menurut agamanya, memilih pendidikan dan pengajaran, memilih pekerjaan, memilih kewarganegaraan, memilih tempat tinggal di wilayah negara dan meninggalkannya, serta berhak kembali; 
15. Setiap orang berhak atas kebebasan meyakini kepercayaan, menyatakan pikiran dan sikap, sesuai dengan hati nuraninya;

16. Setiap orang berhak atas kebebasan berserikat, berkumpul dan mengeluarkan pendapa;t

17. Setiap orang berhak untuk berkomunikasi dan memperoleh informasi untuk mengembangkan pribadi dan lingkungan sosialnya, serta berhak untuk mencari, memperoleh, memiliki, menyimpan, mengolah, dan menyampaikan informasi dengan menggunakan segala jenis saluran yang tersedia;

18. Setiap orang berhak atas perlindungan diri pribadi, keluarga, kehormatan, martabat, dan harta benda yang di bawah kekuasaannya, serta berhak atas rasa aman dan perlindungan dari ancaman ketakutan untuk berbuat atau tidak berbuat sesuatu yang merupakan hak asasi;

19. Setiap orang berhak untuk bebas dari penyiksaan atau perlakuan yang merendahkan derajat martabat manusia dan berhak memperoleh suaka politik dari negara lain;

20. Setiap orang berhak hidup sejahtera lahir dan batin, bertempat tinggal, dan mendapatkan lingkungan hidup yang baik dan sehat serta berhak memperoleh pelayanan kesehatan;

21. Setiap orang berhak mendapat kemudahan dan perlakuan khusus untuk memperoleh kesempatan dan manfaat yang sama guna mencapai persamaan dan keadilan;

22. Setiap orang berhak atas jaminan sosial yang memungkinkan pengembangan dirinya secara utuh sebagai manusia yang bermartabat;

23. Setiap orang berhak mempunyai hak milik pribadi dan hak milik tersebut tidak boleh diambil alih secara sewenang-wenang oleh siapapun;

24. Hak untuk hidup, hak untuk tidak disiksa, hak untuk kemerdekaan pikiran dan hati nurani, hak beragama, hak untuk tidak diperbudak, hak untuk diakui sebagai pribadi dihadapan hukum, dan hak untuk tidak dituntut atas dasar hukum yang berlaku surut adalah hak asasi manusia yang tidak dapat dikurangi dalam keadaan apapun;

25. Setiap orang bebas dari perlakuan yang bersifat diskriminatif atas dasar apapun dan berhak mendapatkan perlindungan terhadap perlakuan yang bersifat diskriminatif itu;

26. Identitas budaya dan hak masyarakat tradisional dihormati selaras dengan perkembangan zaman dan peradaban;

27. Perlindungan, pemajuan, penegakan, dan pemenuhan hak asasi manusia adalah tanggung jawab negara, terutama pemerintah;

28. Untuk menegakkan dan melindungi hak asasi manusia sesuai dengan prinsip negara hukum yang demokratis, maka pelaksanaan hak asasi manusia dijamin, diatur, dan dituangkan dalam peraturan perundang-undangan;

29. Setiap orang wajib menghormati hak asasi manusia orang lain dalam tertib kehidupan bermasyarakat, berbangsa, dan bernegara

30. Dalam menjalankan hak dan kebebasannya, setiap orang wajib tunduk kepada pembatasan yang ditetapkan dengan undang-undang dengan maksud semata-mata untuk menjamin pengakuan serta penghormatan atas hak dan kebebasan orang lain dan untuk memenuhi tuntutan yang adil sesuai dengan pertimbangan moral, nilai-nilai agama, keamanan, dan ketertiban umum dalam suatu masyarakat demokratis

31. Negara menjamin kemerdekaan tiap-tiap penduduk untuk memeluk agamanya masing-masing dan untuk beribadat menurut agamanya dan kepercayaannya itu

32. Tiap-tiap warga negara berhak dan wajib ikut serta dalam usaha pertahanan dan keamanan negara

33. Setiap warga negara berhak mendapat pendidikan;

34. Bumi dan air dan kekayaan alam yang terkandung di dalamnya dikuasai oleh negara dan dipergunakan untuk sebesar-besar kemakmuran rakyat;

35. Fakir miskin dan anak-anak terlantar dipelihara oleh negara; 
36. Negara bertanggung jawab atas penyediaan fasilitas pelayanan kesehatan dan fasilitas pelayanan umum yang layak.

Demikian hak-hak konstitusionalitas warga negara yang di jamin dalam UUD 1945, karena ia adalah hak maka negara wajib untuk mewujudkan serta mengusahakan hak-hak tersebut. Apabila negara melakukan pelanggaran terhadap hak-hak yang ada, maka warga negara dapat menuntut untuk membatalkan kebijakan tersebut. Jika kebijakan itu dalam bentuk undang-undang maka permohonan untuk membatalkan UU tersebut melalui Mahkamah Konstitusi (MK). Namun jika di bawah UU maka pengujiannya melalui Mahkamah Agung (MA).

\section{Hak Konstitusional waga negara dalam kehidupan berdemokrasi?}

Menjadi Warga Negara Republik Indonesia menurut UUD 1945 mempunyai arti yang sangat penting dalam sistem hukum dan pemerintahan. UUD 1945 mengakui dan menghormati hak asasi setiap individu manusia yang berada dalam wilayah negara Republik Indonesia. Penduduk Indonesia, apakah berstatus sebagai Warga Negara Indonesia atau bukan diperlakukan sebagai manusia yang memiliki hak dasar yang diakui universal. Prinsip-prinsip hak asasi manusia itu berlaku pula bagi setiap individu Warga Negara Indonesia. Bahkan, di samping jaminan hak asasi manusia itu, setiap Warga Negara Indonesia juga diberikan jaminan hak konstitusional dalam UUD 1945.

Begitu ula dalam kehidupan demokrasi. Setiap warga masyrakat juga memiliki hak konstitusional dalam demokrasi. Secara epistimologi demokrasi berasal dari bahasa yunani yakni Demos yang berarti rakyat dan Kratos/kratein yang berarti kekuasaan. Sehingga melahirkan pengertian rakyat berkuasa,pemerintahan dari rakyat. Oleh Abraham Lincoln "pemerintahan dari,oleh dan untuk rakyat.

Dari arti terminologis demokrasi diartikan sbg suatu sistem pemerintahan dimana rakyat diikutsertakan dalam pemerintahan negara.

Konsep demokrasi mengandung pengertian utama yaitu bahwa kedaulatan politik itu berada ditangan rakyat. Yang menjadi perbedaan ialah dalam cara bagaimana kedaulatan rakyat itu diatur dan dilaksanakan.

Selain mempunyai hak dan kewajiban, warga negara juga mempunyai fungsi dan tanggung jawab dalam proses demokrasi. Dalam negara demokrasi, tiap warga negara berfungsi sebagai subjek sekaligus objek maksudnya rakyatlah yang menjalankan proses, pemerintahan dan hasilnya ditujukan untuk kepentingan rakyat pula.

Secara lahiriah, hanya beberapa orang yang duduk di lemabga perwakilan. Namun, mereka mengemban amanat seluruh rakyat Indonesia. Rakyat bertanggung jawab dalam pelaksaaan kehidupan demokrasi. Dengan kata lain, seluruh rakyat Indonesia harus mewujudkan situasi negara yang kondusif, aman, tertib dan demokratis. Untuk mewujudkan hal tersebut dengan cara menjalankan semua kewajiban terhadap negara. Dengan menjalankan kewajiban terhadap negara, maka secara otomatis negarapun akan menjalankan kewajiban yaitu dengan pemenuhan hak rakyat secara maksimal.

Lantas apa saja Hak Konstitusional Warga Negara dalam bingkai Negara Demokrasi?

1. Hak Politik dalam Pemerintahan

- Pasal 1 ayat (2)

- Psal 27 ayat (1) "Segala WN bersmaan kedudukannya di dalam hukum \& pemerintahan wajib menjunjung hukum dan pemerintahan"

- Pasal 28D ayat (3) "Setiap WN berhak memperoleh kesempatan yang sama dalam pemerintahan"

Implementasinya diatur dalam Pasal

- Pasal 2 ayat (1)

- Pasal 6A ayat (1) 
- Pasal 19 ayat (1)

- Pasal 22C ayat (1)

Dalam Pasal 22 C ayat (1) tersebut mengarahkan bahwa negara harus memenuhi segala bentuk hak warga negaranya, khususnya berkaitan dengan hak politik warga negara dan secara khusus tentang hak dipilih dan memilih dalam proses demokrasi yaitu pengunaan hak pilih dalam Pemilu

2. Kebebasan berpendapat

- Pasal 28 "kemerdekaan berserikat \& berkumpul mengeuarkan pikiran secara lisan \& tulisan dan sebagainya ditetapkan dlm UU

- Pasal 28 E ayat (3) "setiap orang berhak atas kebebasan berserikat, berkumpul, dan mengeuarkan pendapat"

Berdasarkan survei dari CSIS dan lembaga survei Cyrus Network

\begin{tabular}{|l|l|l|l|}
\hline No. & Pemilu & Partisipasi Masyarakat & Golput \\
\hline 1. & 1955 & $91,4 \%$ & $8,6 \%$ \\
\hline 2. & 1971 & $96,6 \%$ & $3,4 \%$ \\
\hline 3. & $1977-1982$ & $96,5 \%$ & $3,5 \%$ \\
\hline 4. & 1987 & $96,4 \%$ & $3,4 \%$ \\
\hline 5. & 1992 & $95,1 \%$ & $4,9 \%$ \\
\hline 6. & 1997 & $93,6 \%$ & $6,4 \%$ \\
\hline 7. & 1999 & $92,6 \%$ & $7,3 \%$ \\
\hline 8. & 2004 & $84,1 \%$ & $15,9 \%$ \\
\hline 9. & Pilpres Putaran 1 & $78,6 \%$ & $21,8 \%$ \\
\hline 10 & Pilpres Putaran 2 & $76,6 \%$ & $23,4 \%$ \\
\hline 11. & 2009 & $70,9 \%$ & $29,1 \%$ \\
\hline 12 & Pipres 2009 & $71,7 \%$ & $28,3 \%$ \\
\hline 13. & 2014 & $75,2 \%$ & $24,8 \%$ \\
\hline
\end{tabular}

Dari data tersebut dapat dilihat bahwa ternyata tingkat partisispasi masyaraat dalam proses demokrasi yakni pemilu cukup rendah. Hal ini bisa dilihat dengan tingginnya masyarakat yang memilih untuk golput. Hal ini dapat dipengaruhi oleh beberapa halPertama, tingkat partisipasi masyarakat dalam pemerintahan rendah. Hal ini bisa dipengaruhi oleh beberapa hal, yakni:

1. Minimnya informasi tentang pentingnya partisipasi masyarakat dalam demokrasi

2. Pendidikan politik yang rendah

3. Apatisme masyarakat

4. Money politic 
Dilain pihak dalam kehidupan demokrasi khususnya dalam kebebsan berpendapat, pun dipengaruhi oleh kebebasan berpendapat dimuka umum yang tak terbatas maupun yang terbatasi. Yakni di satu sisi diberikan kebebasan yang tidak terbatas namun di sisi lain ada pembatasan oleh pemerintah, sehingga dalam proses demokrasi kadang masyarakat terlalu kebablasan dalam mengemukan pendapat. Ataupun kasus lain pemerintah dapat serta merta membungkam kebebasan masyarakat dalam berpendapat dengan kriminalisasi menggunakan UU ITE.

Dari beberapa hal yang telah disampaikan, maka kesimpulan Perlunya pemahaman dan penanaman terhadap hak-hak konstitusional warga negara, dengan hal ini diharapkan setiap warga negara melaksanakan kewajiban konstitusionalnya sebagai warga negara.

\section{Kesimpulan dan Saran}

Beberapa kesimpulan yang dapat ditarik dari kegiatan pengabdian di SMA N 1 Bantul adalah sebagai berikut:

1. Tingkat pengetahuan sebagian siswa sudah cukup baik terkait dengan hak konstitusional warga negara. Namun sifatnya masih sangat mendasar, siswa-siswa mulai kebingungan jika sudah mendetail masuk ke inti pembahasan materi (terutama terkait Hak Asasi Manusia). Hal ini disebabkan oleh minimnya fasilitas yang dapat diakses oleh peserta didik. Selain itu, jumlah peserta didik yang telah memahami dengan baik hak konstitusional warga negara ini jumlahnya jauh lebih sedikit dibandingkan dengan jumlah keseluruhan siswa.

2. Selama ini, tidak ada kurikulum dari sekolah yang berbicara mengenai hak konstitusional warga negara kepada siswa-siswi. Memang telah ada mata pelajaran Pendidikan Kewargaan dan Pancasila, namunsifatnya sangat terbatas baik dari materi maupun pengajarnya, sehingga belum berperan aktif dalam mengenalkan hak konstitusional warga negara kepada siswa. Dengan adanya sosialisasi yang seperti ini, melalui metode yang lebih testruktur dan sistematis, apresiasi dari siswa-siswi lebih besar dan substansi materi mudah dipahami.

3. Melalui sosialisasi hak konstitusional warga negara ini, seluruh peserta selain menjadi mengetahui hak apa saja yang ia miliki, juga menjadi tahu upaya apa yang dapat dia lakukan jika hak konstitusionalnya di langgar.

Sebagai tindak lanjut maka, ada beberapa saran yang dapat disampaikan, diantaranya:

1. Untuk mem follow up kegiatan, perlu untuk melanjutkan sosialisasi yang serupa pada tahuntahun berikutnya. Agar siswa-siswi lain juga memahami dan mengetahui hak konstitusionalnya sebagai warga negara. Hal ini penting dilakukan mengingat jumlah peserta dalam kegiatan sosialisasi ini sangat terbatas sehingga tidak semua siswa dapat ikut serta.

2. Kepada wakil kepala sekolah bidang akademik agar memberikan kurikulum terkait dengan hak konstitusional warga negara mengingat pentingnya hal ini untuk diketahui.

3. Kepada seluruh siswa-siswi agar dapat berperan aktif dalam memperdalam ilmu pengetahuan, tidak terkecuali pengetahuan tentang hak konstitusional warga negara.

\section{Daftar Pustaka}

Despan Heryansyah, Tanggung Jawab Pemuda dalam Masa Depan Pancasila, Jurnal Hukum Ius Quia Iustum, Jurnal Hukum FH UII, Vol. 21, No 4, Oktober 2014.

Bagir Manan, Teori dan Politik Konstitusi, Cetakan Kedua, FH UII Press, Yogyakarta, 2003. , DPR, DPD, dan MPR dalam UUD 1945 Baru. Cetakan Petama, FH UII Press, Yogyakarta, 2003.

Hans Kelsen, General Theory if Law and State, Russell \& Russell, New York, 1973.

Jimly Ashiddiqie, Konstitusi dan Konstitusionalisme Indonesia, Sinar Grafika Offset, Jakarta, 2011. 
MK-RI, Pendidikan Kesadaran Berkonstitusi, Cet.6, Sekretariat Jenderal dan Kepaniteraan Mahkamah Konstitusi Republik Indonesia, Jakarta, 2010.

Muhammad Yamin, Naskah Persiapan UUD 1945, jilid pertama, Jakarta. 1959.

Miriam Budiardjo, Dasar-dasar Ilmu Politik, Gramedia Pustaka Utama, Jakarta, 1991.

Moh. Mahfud MD, Politik Hukum di Indonesia, cetakan Kelima, Rajawali Pers, Jakarta, 2012.

Ni'matul Huda, Negara Hukum, Demokrasi, dan Judicial Review, Cetakan Pertama, UII Press, Yogyakarta, 2005. , hukum tata negara Indonesia edisi revisi, cetakan ke-9, Raja Grafindo persada, Yogyakarta, 2014. 